\title{
KEBIJAKAN TERTIB ADMINISTRASI PERTANAHAN DESA
}

\author{
Umi Supraptiningsih \\ (Dosen Tetap Jurusan Syari'ah STAIN Pamekasan)
}

\begin{abstract}
Abstrak:
Penertiban administrasi desa merupakan langkah awal menuju perlindungan dan kepastian hukum. Tindakan harus dilakukan oleh kepala desa atau kepala kelurahan dengan melakukan pencatatan atas bidang-bidang tanah, bilamana terjadi peralihan atau pembebanan hak atas tanah. Penerapan berbagai peraturan merupakan tindakan preventif dalam menjaga dan melindungi hak warganya serta tanah aset desa (tanah kas desa) tersebut. Berkenaan dengan tanah kas desa, perlu dilakukan pendaftaran tanah, sehingga ada kepastian hukum. Tidak dilakukan peralihan dan pembebanan hak atas tanah kas desa kecuali untuk kepentingan umum, begitu pula hasil pembayaran ganti ruginya harus dibelikan tanah kas desa lagi yang kualitasnya sama atau lebih bagus.
\end{abstract}

Kata Kunci :

tertib administrasi, kepala desa, dan tanah kas desa.

\section{Pendahuluan}

Lahirnya UUPA tanggal 24 September 1960 sebagai tonggak sejarah berlakunya hukum tanah nasional, yang secara otomatis menghapus aturan yang bersifat dualisme ${ }^{1}$ sehingga ada unifikasi hukum tanah nasional yang terdapat dalam UUPA. UUPA itu sendiri berasaskan pada hukum adat ${ }^{2}$, yaitu hukum adat yang telah disaring (disaneer) dan sesuai dengan jiwa bangsa Indonesia. Hukum adat yang menjadi dasar hukum agraria nasional harus memenuhi syarat-

1 Dualisme hukum yang berlaku sebelum UUPA lahir, maksudnya pada garis besarnya ada dua aturan hukum yang berlaku pada saat itu yaitu selain hukum adat juga diberlakukan hukum barat yang bersumber pada BW (Burgelijk Wetboek)

${ }^{2}$ Lihat penjelasan pasal 5 UUPA 
syarat3: (1) Tidak boleh bertentangan dengan tujuan nasional dan negara berdasarkan atas persatuan bangsa; (2) tidak boleh bertentangan dengan sosialisme Indonesia; (3) tidak boleh bertentangan dengan peraturan yang tercantum dalam UndangUndang Pokok Agraria; dan (4) tidak boleh bertentangan dengan peraturan-peraturan perundangan yang berlaku.

Refleksi dari politik hukum agraria yang terdapat dalam UUPA, mengakibatkan masyarakat hukum adat seringkali terabaikan hak-haknya. Sebelum UUPA lahir, hak ulayat masyarakat yang mencakup seluruh tanah di wilayah masyarakat hukum adat tersebut, seperti nagari desa, marga, huta, dan sebagainya, baik yang telah dikuasai dan didayagunakan maupun dalam bentuk tanah kosong.4

Datangnya penjajah di Indonesia, telah membuat berbagai perubahan di Indonesia baik dalam soal pemilikan Hak Atas Tanah maupun persoalan kepastian hukum (ketentuan hukumnya), sebagai contoh pelaksanaan politik pertanahan yang dijalankan dengan cara menjual tanah kepada orang-orang yang mempunyai modal besar terutama Cina, Arab, dan Belanda, yang selanjutnya disebut dengan tanah partikeli". Dengan politik ini Belanda hendak melahirkan tuantuan tanah yang lebih-lebih lagi menindas rakyat, munculah semacam negara-negara kecil dan rakyat di wilayahnya diperlakukan sebagai budak-budak. ${ }^{5}$ Begitu pula setelah Indonesia merdeka, ada akibat hukum yang ditimbulkan yang selanjutnya juga menimbulkan suatu persoalan/masalah yang hingga saat ini masih belum bisa terselesaikan.

Politik pemerintahan pun juga menciptakan suatu kondisi yang lebih terang. Pada zaman Orde Baru, masyarakat bungkam tidak berani untuk menyuarakan apa yang menurut mereka menjadi haknya akan tetapi begitu kran reformasi dibuka berbagai persoalan tanah diungkap seperti kasus penggaraman di pulau Madura, kasus Jenggawah di Jember. Persoalan tersebut hingga kini juga belum bisa

3 Soetomo, Politik dan Administrasi Agraria, (Surabaya: Usaha Nasional, 1986), hlm. 34 35

${ }^{4}$ Fifi Junita, "Hak Ulayat Hukum Adat Setelah Berlakunya Undang-Undang No. 5 Tahun 1960 tentang Pokok-Pokok Ketentuan Agraria”, Yuridika, Volume 16 No. 5, (September 2001), hlm. 490

5 Ibid, hlm. 18-19 
terselesaikan, masyarakat melakukan suatu gerakan-gerakan penuntutan untuk pengembalian lahan yang menurut mereka merupakan tanah nenek moyangnya hasil membuka hutan, karena pada masa Hindia Belanda ada asas yang kita kenal dengan domein verklaring 6 yang dikeluarkan oleh pemerintah Hindia Belanda, maka lahan tersebut jatuh pada negara (saat itu Hindia Belanda), untuk selanjutnya pemerintah kolonial dapat menyewakan tanah-tanah kepada perusahaan onderneming dengan skala besar. ${ }^{7}$

Pelaksanaan tertib administrasi dibidang pertanahan juga tidak lepas dengan peran kepala desa sebagai pejabat terendah di lingkungan desa yang mempunyai tugas dan kewenangan melakukan pembukuan tentang kepemilikan dari suatu bidang tanah diharapkan untuk lebih teliti dan tertib melakukan pembukuan. Baik berkenaan dengan kepemilikan, peralihan hak akibat perbuatan hukum maupun peralihan hak bukan karena perbuatan hukum (waris). Sehubungan dengan pengajuan permohonan pendaftaran tanah untuk hak atas tanah milik adat, kepala desa memegang peranan yang penting sekali. ${ }^{8}$ Di sinilah dibutuhkan sosok kepala desa yang bertanggung jawab.

Awal timbulnya sengketa tanah dikalangan masyarakat lebih banyak dilatar belakangi dengan catatan yang tertera pada buku desa atau Letter $C$, walaupun Letter $C$ tidak mempunyai kekuatan bukti yang mutlak bahwa nama yang tercantum di dalamnya adalah pemiliknya, begitu pula ketitir ${ }^{9}$. Namun, pada kenyataan di lapangan setiap pelaksanaan proses pendaftaran tanah untuk pertama kali baik secara sistematik maupun secara sporadik, catatan dalam Letter C dipakai sebagai salah satu alas bukti hak kepemilikan seseorang atas sebidang tanah selain bukti yang lain, yakni keterangan kesaksian

6 Domein verklaring artinya adalah bahwa barang siapa yang tidak dapat menunjukkan tanah tersebut adalah haknya (bukti kepemilikan), maka tanah itu jatuh pada negara. Pada masa itu, tertib administrasi pertanahan di desa tidak seperti yang ada sekarang. Saling percaya antar sesama warga masih dijunjung tinggi.

7 Andrian Sutedi, Implementasi Prinsip Kepentingan Umum - dalam Pengadaan Tanah Untuk Pembangunan, (Jakarta: Sinar Grafika, 2007), hlm. 8

8 Bachtiar Effendie, Kumpulan Tulisan tentang Hukum Tanah, (Bandung: Alumni, 1993), hal 74.

9 Rusman Murad, Penyelesaian Sengketa Hukum atas Tanah, (Bandung: Alumni, 1991), hlm. 56 
dari tokoh atau perangkat desa yang mengetahui betul tentang sejarah kepemilikan dari bidang tanah dimaksud.

Beberapa sengketa tanah yang muncul dipermukaan baik yang sudah diselesaikan melalui litigasi maupun non litigasi dan yang sampai saat ini belum ada penyelesaiannya, lebih banyak didasarkan pada hak kepemilikan tanah yang tercatat dalam buku desa atau Letter C. Lebih-lebih program pemerintah yang akhir-akhir ini telah dilaksanakan berupa penyertifikatan secara serentak, ajudikasi, atau melalui prona, ternyata di lapangan banyak menimbulkan masalah baru di kalangan masyarakat. Tujuan pemerintah mengadakan ajudikasi tidak lain untuk tertib administrasi yang menuju pada kepastian hukum atas bidang tanah baik kepastian subyek hukum maupun kepastian obyek hukumnya. Akan tetapi begitu catatan buku desa atau letter $C$ dicocokkan dengan kondisi dilapangan banyak terjadi ketimpangan, baik berkenaan dengan subyek haknya maupun obyeknya. Sehingga tidak dapat dielakkan bahwa catatan buku desa atau letter $C$ tetap dipergunakan sebagai salah satu dasar alas hak tentang kepemilikan hak atas tanah.

Kunci yang paling utama dalam paparan di atas adanya tertib administrasi di tingkat desa, yang mana catatan buku desa atau letter $C$ tentunya berada penuh dibawah penguasaan kepala desa. Sehingga diperlukan tindakan kehati-hatian dan kejujuran dari kepala desa dan perangkatnya dalam setiap terjadi perbuatan hukum berkenaan dengan bidang tanah atau melakukan perubahan (mutasi).

Selain tertib administrasi yang menjadi kewajiban pemerintah untuk melaksanakan secara terus menerus, juga dibutuhkan kesadaran hukum bagi masyarakat khususnya pemegang hak atas tanah untuk selalu melakukan pendaftaran hak atas tanah yang menjadi hak mereka. Baik pendaftaran untuk pertama kalinya maupun pendaftaran hak setiap terjadi perbuatan hukum (jual beli, tukar menukar, hibah, pemisahan hak bersama, pemasukan dalam perseroan (inbreng), hak tanggungan dan gadai) dan waris. Sering terjadinya pengabaikan dikalangan masyarakat dalam proses perbuatan hukum, semisal terjadi jual beli, secara fisik obyek jual beli sudah beralih kepada pembeli dan penjual sudah menerima uang pembayaran secara kontan, namun perbuatan hukum tersebut tidak dituangkan dalam bentuk akta dan juga tidak dilakukan pendaftaran tanah serta mereka tidak memperkirakan apa yang akan terjadi 
dikemudian hari. Begitu pula kasus tanah wakaf, yang juga sering terjadi dikalangan masyarakat, begitu si wakif meninggal dunia, ahli warisnya melakukan tuntutan hak dengan dalih bahwa tanah wakaf tersebut masih menjadi hak ahli waris. Dengan tidak dilakukannya perbuatan hukum dan pendaftaran tanah secara tertib oleh pemegang hak, hal ini akan rentan menimbulkan masalah. Sebagaimana yang telah diamanatkan Pasal 19 ayat (1) UUPA, yang menyebutkan bahwa "Untuk menjamin kepastian hukum oleh Pemerintah diadakan pendaftaran tanah di seluruh wilayah Republik Indonesia menurut ketentuan-ketentuan yang diatur dengan Peraturan Pemerintah". Akhirnya terbitlah Peraturan Pemerintah (PP) No. 10 Tahun 1961 yang selanjutnya mengalami pergantian dengan PP No. 24 Tahun 1997.

Tertib administrasi bukan saja harus dilakukan oleh pemerintah dan masyarakat selaku pemilik atau pemegang hak atas tanah akan tetapi juga tertib administrasi yang harus dilakukan oleh kepala desa atas tanah percaton dan kas desa ${ }^{10}$. Sehingga bidangbidang tanah itupun akan ada kepastian hukum, baik kepastian atas pemegang hak (subyek) dan kepastian obyeknya. Hal yang demikian seringnya terjadi bilamana ada pergantian kepala desa, tanah percaton dan tanah kas desa tidak juga ikut diserahkan kepada kepala desa baru (penggantinya). Kondisi yang demikian sangat menimbulkan persoalan. Bahkan lebih parahnya lagi, oleh kepala desa yang sebelumnya bidang-bidang tanah tersebut telah digadaikan lebih dahulu dengan jangka waktu yang cukup lama, sehingga begitu terjadi pergantian kepala desa, tanah percanton tersebut masih berstatus gadai.

Sebagaimana kasus yang terjadi di Desa Bujur Timur, Kecamatan Batumarmar, Kabupaten Pamekasan, yang pada akhirnya menimbulkan kasus carok masal antara pendukung kepala desa lama dan pendukung kepala desa baru. Kasus tersdebut berawal dari kasus tanah percaton yang oleh kepala desa lama tidak diserahkan kepada kepala desa baru.

\footnotetext{
10 Tanah percaton adalah tanah milik desa yang dipergunakan untuk kesejahteraan kepala desa dan perangkat desa. Sedangkan tanah kas desa (bondo desa) adalah tanah milik desa yang dipergunakan dalam rangka memenuhi kebutuhan desa.
} 
Begitu pula terjadi pada tanah percaton dan kas Desa yang status Desanya sudah berubah menjadi Kelurahan, hal ini juga menimbulkan persoalan, apakah tanah percaton atau kas desa tersebut tetap menjadi aset kelurahan ataukah menjadi aset pemerintah daerah? Yang hingga kini persoalan tersebut masih menjadi tarik ulur dan belum ada kepastian atau penyelesaiannya.

Dikeluarkan Keputusan Menteri Dalam Negeri No. 28 Tahun 2006 tentang Pembentukan, Penghapusan, Pengabungan Desa dan Perubahan Status Desa menjadi Kelurahan dalam salah satu pasalnya yaitu pasal 12 menyatakan bahwa: (1) Berubahnya status Desa menjadi Kelurahan, seluruh kekayaan dan sumber-sumber pendapatan Desa menjadi kekayaan Daerah Kabupaten/Kota; (2) Kekayaan dan sumber-sumber pendapatan sebagaimana dimaksud dalam ayat (1) dikelola oleh Kelurahan bersangkutan untuk kepentingan masyarakat setempat.

Ketentuan di atas, memberikan suatu kewenangan bagi pemerintah daerah untuk melakukan pengurusan semata, tidak mempunyai kewenangan untuk memberikan atau mengalihkan kepihak lain. ${ }^{11}$ Namun apa yang terjadi pada kenyataan di lapangan? Tanah-tanah tersebut dikapling menjadi lahan siap bangun dan dialihkan (dijual) kepada rakyat, entah ke mana hasil dari penjualan bidang tanah tersebut. Itulah gambaran ketidaktertiban administrasi di bidang pertanahan yang menimbulkan berbagai sengketa.

Atas dasar amanat pasal 33 ayat (3) UUD 1945, yang menyebutkan bahwa, "Bumi, air, dan kekayaan alam yang terkandung di dalamnya dikuasai oleh negara dan dipergunakan untuk sebesar-besar kemakmuran rakyat". Kalimat "dikuasai oleh negara" mengandung makna dan tanggung jawab yang besar dari negara atas kemakmuran seluruh rakyat Indonesia. Selanjutnya amanat pasal 33 ayat (3) dijabarkan ke dalam pasal 2 UUPA, yang berbunyi sebagai berikut :

1. Atas dasar ketentuan dalam pasal 33 ayat (3) Undang-Undang Dasar 1945 dan hal-hal yang dimaksud dalam pasal 1, bumi, air dan ruang angkasa termasuk kekayaan alam yang terkandung

11Sri Winarsi, "Pengelolaan Tanah Kas Desa di Era Otonomi Daerah", Yuridika, Vol. 29 No. 5, (September 2005), hlm. 412. 
di dalamnya itu pada tingkatan tertinggi dikuasai oleh negara, sebagai organisasi kekuasaan seluruh rakyat.

2. Hak menguasai negara termaksud dalam ayat (3) UndangUndang Dasar 1945 dan hal-hal sebagai dimaksud dalam pasal 1 memberi wewenang untuk: (a) Mengatur dan menyelenggarakan peruntukan, penggunaan, persediaan bumi, air dan ruang angkasa tersebut, menentukan dan mengatur hubungan-hubungan hukum antara orang-orang dengan bumi, air dan ruang angkasa; (b) menentukan dan mengatur hubungan-hubungan hukum antar orang-orang dengan bumi, air, dan ruang angkasa tersebut; (c) menentukan dan mengatur hubungan-hubungan hukum antara orng-orang dan perbuatan hukum yang mengenai bumi, air dan ruang angkasa.

3. Wewenang yang bersumber pada hak menguasai negara tersebut pada ayat (3) pasal ini digunakan untuk mencapai sebesar-besar kemakmuran rakyat dalam arti kebahagiaan, kesejahteraan, dan kemerdekaan dalam masyarakat dan negara hukum Indonesia menurut ketentuan Peraturan Pemerintah. ${ }^{12}$

Berangkat dari ketentuan di atas, maka menjadi kewajiban negara dalam rangka melakukan penertiban hak atas tanah, baik berkenaan dengan peruntukan, pengunaan, pemeliharaan serta melakukan penertiban atas hubungan hukum antara bidang tanah dengan pemegangnya (subyek hukum) serta melakukan penertiban atas perbuatan-perbuatan hukum yang dilakukan oleh subyek hukum terhadap hak atas tanah. Hal tersebut dilakukan dalam rangka menuju terwujudnya kepastian hukum.

\section{Hak Penguasaan atas Tanah}

Sebelum diberlakukannya UUPA, dalam hal hukum tanah di Indonesia berlaku bersamaan berbagai perangkat hukum agraria. Di samping bersumber pada hukum adat yang berkonsepsi komunalistik religius, yang merupakan hukum yang berlaku bagi mayoritas penduduk Indonesia, ada juga yang bersumber pada hukum Barat

12Mohammad Hatta, Hukum Tanah Nasional dalam Perspektif Negara Kesatuan, (Yogyakarta: Media Abadi, 2005), hlm. 2. 
yang berkonsepsi individualistik liberal serta ada pula yang berasal dari berbagai bekas pemerintahan Swapraja yang umumnya berkonsepsi feodal. Dualisme dalam hukum perdata tersebut memerlukan tersedianya perangkat hukum yang terdiri atas peraturan-peraturan dan asas-asas yang memberikan jawaban, hukum apa atau hukum yang mana yang berlaku dalam menyelesaikan kasus-kasus hukum antar golongan dibidang agraria. Dengan demikian, setelah berlakunya UUPA, hukum yang berlaku atas bumi, air, dan ruang angkasa adalah Hukum Agraria Nasional. ${ }^{13}$

Dalam UUPA kita mengenal macam-macam hak atas tanah sebagaimana yang telah dijabarkan dalam Pasal 16 ayat (1) dan Pasal 53 UUPA, yang menurut sifatnya dapat dikelompokkan menjadi 3 bidang, yaitu: Pertama, hak atas tanah yang bersifat tetap. Macammacam hak atas tanah ini adalah Hak Milik (HM), Hak Guna Usaha (HGU), Hak Guna Bangunan (HGB), Hak Pakai (HP), Hak Sewa Untuk Bangunan (HSUB), Hak Membuka Tanah, dan Hak Memungut Hasil Hutan. Kedua, hak atas tanah yang akan ditetapkan dengan Undang-undang. Macam hak atas tanah ini belum ada. Ketiga, hak atas tanah yang bersifat sementara. Macam-macam hak atas tanah ini adalah Hak Gadai (Gadai Tanah), Hak Usaha Bagi Hasil (Perjanjian Bagi Hasil), Hak Menumpang, dan Hak Sewa Tanah Pertanian.

Sistem UUPA dalam menentukan macam hak atas tanah tidak bersifat tertutup, artinya UUPA masih membuka peluang adanya perubahan penambahan hak atas tanah selain yang ditentukan dalam Pasal 16 ayat (1). Hal ini dapat diketahui secara implisit dari Pasal 16 ayat (1) huruf h UUPA yang menyatakan bahwa hak-hak lain yang akan ditentukan dengan Undang-undang. ${ }^{14}$

Ruang lingkup agraria menurut UUPA, meliputi bumi, air, ruang angkasa, dan kekayaan alam yang terkandung di dalamnya. Ruang lingkup bumi meliputi permukaan bumi, dan tubuh bumi di bawahnya serta yang berada di bawah air. Permukaan bumi sebagai bagian dari bumi juga disebut tanah. Tanah yang dimaksudkan di sini bukan mengatur tanah dalam segala aspeknya, melainkan hanya

13Irawan Soerodjo, Kepastian Hukum Hak Atas tanah di Indonesia, (Surabaya: Arkola, 2003), hlm. 3.

14Sumardji, "Eksistensi, Pendaftaran, dan Pembebanan Hak Pengelolaan", Yuridika, Vol. 15 No. 1, (Januari 2000), hlm. 58. 
mengatur salah satu aspeknya, yaitu tanah dalam pengertian yuridis yang disebut hak penguasaan atas tanah.

Menurut Boedi Harsono, hak penguasaan atas tanah berisi serangkaian wewenang, kewajiban dan/atau larangan bagi pemegang haknya untuk berbuat sesuatu mengenai tanah yang dihaki. Sesuatu yang boleh, wajib atau dilarang untuk diperbuat, yang merupakan isi hak penguasaan itulah yang menjadi kriterium atau tolok pembeda di antara hak-hak penguasaan atas tanah yang diatur dalam Hukum Tanah. ${ }^{15}$

Dalam UUPA dimuat hierarkhi hak-hak penguasaan atas tanah, yaitu: (1) Hak bangsa Indonesia yang disebut dalam pasal 1, sebagai hak penguasaan atas tanah yang tertinggi, beraspek perdata dan publik; (2) hak menguasai dari Negara yang disebut dalam pasal 2, semata-mata beraspek publik; (3) hak ulayat masyarakat hukum adat, yang disebut dalam pasal 3, beraspek perdata dan publik; (4) Hak perorangan/individual, semuanya beraspek perdata, terdiri atas: (a) hak-hak atas tanah, sebagai hak-hak individu yang semuanya secara langsung ataupun tidak langsung bersumber pada hak Bangsa, yang disebut dalam pasal 16 dan 53; (b) wakaf, yaitu hak milik yang sudah diwakafkan pasal 49; dan (c) hak jaminan atas tanah yang disebut "hak tanggungan", dalam pasal 25,33, 39 dan 51.16

Hak penguasaan atas tanah yang tertinggi adalah hak bangsa Indonesia atas tanah. Hak bangsa Indonesia atas tanah mempunyai sifat komunalistik, artinya semua tanah yang ada dalam wilayah Republik Indonesia merupakan tanah bersama rakyat Indonesia, yang bersatu sebagai Bangsa Indonesia (Pasal 1 ayat (1) UUPA). Hak Bangsa Indonesia atas tanah juga mempunyai sifat religius, artinya seluruh tanah yang ada dalam wilayah Republik Indonesia merupakan karunia Tuhan Yang Maha Esa (Pasal 1 ayat (2) UUPA). Hubungan antara Bangsa Indonesia dengan tanahnya bersifat abadi, artinya hubungan antara bangsa Indonesia dengan tanah akan berlangsung tiada terputus untuk selama-lamanya. Sifat abadi artinya selama rakyat Indonesia masih bersatu sebagai bangsa Indonesia dan selama tanah bersama tersebut masih ada pula, dalam keadaan yang

\footnotetext{
${ }^{15}$ Boedi Harsono, Hukum Agraria Indonesia; Himpunan Peraturan-peraturan Hukum Tanah, (Jakarta: Djambatan, 2006), hlm. 24.

16 Ibid
} 
Umi Supraptiningsih

bagaimanapun tidak ada satu kekuasaan yang akan dapat memutuskan atau meniadakan hubungan tersebut (Pasal 1 ayat (3) UUPA).

\section{Hubungan Antara Negara Dengan Tanah}

Pasal 33 ayat (3) Undang-undang Dasar 1945 tersebut dipakai sebagai landasan Konstitutional agraria di Indonesia, yang berbunyi "Bumi, air, dan kekayaan alam yang terkandung di dalamnya dikuasai oleh Negara dan dipergunakan untuk sebesarbesarnya kemakmuran rakyat". Ketentuan ini memberikan tanggung jawab yang besar kepada Negara agar bumi, air, dan kekayaan alam yang terkandung di dalamnya diletakkan dalam penguasaan oleh Negara, dengan tujuan penguasaan tersebut adalah dipergunakan untuk sebesar-besarnya kemakmuran rakyat. Menurut Muhammad Bakri, kemakmuran yang akan dicapai adalah kemakmuran untuk sebanyak mungkin orang tanpa melanggar hak orang lain. ${ }^{17}$ Masih dalam bukunya Muhammad Bakri, yang dikutip dari Disertasi A. Sodiki, menyatakan bahwa kemakmuran adalah terminologi ekonomi, suatu masyarakat dikatakan makmur apabila masyarakat yang bersangkutan dapat memenuhi dan dipenuhi kebutuhannya baik pisik maupun non pisik secara terus menerus. Indikasi terdapatnya kemakmuran apabila terpenuhi "basic needs" (sandang, pangan, papan, harga diri, kenyamanan, ketentraman hidup, aktualisasi diri), terjamin lapangan kerja (dalam arti luas), adanya pemerintah negara yang bersih, berwibawa dan efektif, serta dirasakannya hukum sebagai bagian penting dari kehidupan ${ }^{18}$.

Itulah yang diharapkan oleh pasal 33 ayat (3) UUD 1945, bahwa kekuasaan negara atas tanah harus dapat memberikan kemakmuran dalam segala aspek yang menjadi kebutuhan dasar bagi kebutuhan hidup seluruh masyarakat. Begitu pula dalam memori penjelasan angka II/2 menegaskan, bahwa perkataan dikuasai dalam pasal 33 ayat (3) UUD 1945 bukanlah berarti dimiliki tetapi pengertian yang memberikan wewenang kepada negara sebagai organisasi kekuasaan dari bangsa Indonesia, sebelumnya disebut sebagai Badan

17Muhammad Bakri, Hak Menguasai Tanah oleh Negara; Paradigma Baru untuk Reformasi Agraria (Jakarta: Citra Media, 2007), hlm. 35

18 Ibid 
Penguasa pada tingkatan tertinggi untuk: (1) Mengatur dan menyelenggarakan peruntukan, penggunaan, persediaan, dan pemeliharaan bumi, air, dan ruang angkasa tersebut; (2) menentukan dan mengatur hubungan-hubungan hukum antara orang-orang dengan bumi, dan lain-lainnya itu (dengan perkataan lain, menentukan dan mengatur hak-hak yang dapat dipunyai atas bumi dan lain-lainnya itu); (3) menentukan dan mengatur hubunganhubungan hukum antara orang-orang dan perbuatan-perbuatan hukum yang mengenai bumi, air, dan ruang angkasa. (Segala sesuatu itu tentunya termasuk juga kekayaan alam yang terkandung di dalamnya). Penegasannya mengenai arti perkataan "dikuasai" dinyatakan dalam pasal 2 ayat (2). ${ }^{19}$

Kewenangan Negara dalam bidang pertanahan yang tertera dalam Pasal 2 ayat (2) UUPA merupakan pelimpahan tugas bangsa untuk mengatur penguasaan dan memimpin penggunaan tanah bersama yang merupakan kekayaan nasional. Tegasnya, hak menguasai Negara atas tanah adalah pelimpahan kewenangan publik dari hak bangsa. Konsekuensinya, kewenangan tersebut hanya bersifat publik semata. ${ }^{20}$

Lebih lanjut dalam pasal 2 ayat (4) UUPA dinyatakan bahwa "pelaksanaan hak menguasai dari negara atas tanah dapat dikuasakan atau dilimpahkan kepada daerah-daerah swatantra (pemerintah daerah) dan masyarakat-masyarakat hukum adat, sekedar diperlukan dan tidak bertentangan dengan kepentingan nasional menurut ketentuan peraturan pemerintah". Selanjutnya dalam penjelasan ayat tersebut dijelaskan bahwa bersangkutan dengan asas otonomi dan medebewind dalam penyelenggaraan pemerintah daerah. Soal agraria menurut sifatnya dan pada asasnya merupakan tugas pemerintah pusat (pasal 33 ayat (3) UndangUndang Dasar). Dengan demikian, maka pelimpahan wewenang untuk melaksanakan hak penguasaan dari Negara atas tanah itu adalah merupakan medebewind. Segala sesuatunya akan

19 Edy Ruchiyat, Politik Pertanahan Nasional sampai Orde Reformasi, (Bandung: PT. Alumni, 2006), hlm. 11

${ }^{20}$ Oloan Sitorus dan Nomadyawati, Hak atas Tanah dan Kondominium; Suatu Tinjauan Hukum, (Jakarta: Dasamedia utama, 1994), hlm. 7. 
diselenggarakan dengan kepentingan nasional. Wewenang dalam bidang agraria dapat merupakan sumber keuangan bagi daerah itu.

Tanah Hak Ulayat

Pengakuan yang diberikan oleh negara kepada masyarakat hukum adat, sebagaimana termaktub dalam pasal 2 ayat (4) sangat jelas adanya. Prinsip pengakuan terhadap hak ulayat dan hak-hak serupa dari masyarakat hukum adat sebagaimana yang dimaksud dalam pasal 3 UUPA serta Peraturan Menteri Negara Agraria/Kepala Badan Pertanahan Nasional No. 5 Tahun 1999 tentang Penyelesaian Masalah Hak Ulayat Masyarakat Hukum Adat. Hak ulayat yang diakui menurut UUPA adalah hak ulayat masyarakat hukum adat yang dianggap masih ada dan apabila terdapat sekelompok orang yang masih merasa terikat oleh tatanan hukum adatnya sebagai warga bersama suatu persekutuan hukum tertentu yang diakui dan menerapkan ketentuan-ketentuan persekutuan tersebut dalam kehidupan sehari-hari. ${ }^{21}$

Memasuki era Reformasi yang diawali tahun 1998, perkembangan adopsi pengakuan, penghormatan, dan perlindungan hak-hak adat dapat kita jumpai dari berbagai peraturan perundangundangan, antara lain dalam UUD 1945 Perubahan Kedua (Tahun 2000), yaitu Pasal 18 B ayat (2) yang menyatakan bahwa negara mengakui dan menghormati kesatuan-kesatuan masyarakat hukum adat beserta hak-hak tradisionalnya sepanjang masih hidup dan sesuai dengan perkembangan masyarakat dan prinsip Negara Kesatuan Republik Indonesia yang diatur dalam undang-undang. Sekanjutnya pasal 28 I ayat (3) menyatakan bahwa identitas budaya dan hak masyarakat tradisional dihormati selaras dengan perkembangan jaman dan peradaban. ${ }^{22}$

Selaras dengan ketentuan pasal 3 UUPA, Sri Hajati berpendapat bahwasanya hak ulayat sebagai representasi hak atas tanah dalam kerangka Hukum Tanah Adat dapat ditegakkan apabila: (1) Hak ulayat atau hak yang serupa dengan itu masih ada (masih merupakan hukum positif) dalam tata kehidupan masyarakat hukum adat; (2) selaras dengan prinsip Negara Kesatuan Republik Indonesia

\footnotetext{
21 Winarsi, Pengelolaan Tanah Kas, hlm. 411

22 Maria S.W. Sumardjono, Tanah dalam Perspektif Hak Ekonomi Sosial dan Budaya, (Jakarta: Kompas, 2008), hlm. 157
} 
sehingga penegakannya harus sesuai dengan kepentingan nasional dan kepentingan negara; (3) tidak bertentangan dengan undangundang dan peraturan lain yang lebih tinggi. Jika demikian halnya, maka derajat kedudukan hukum tanah adat berada di bawah UUPA atau hukum pertanahan nasional. ${ }^{23}$

Menurut pendapat Teer Haar Bzn, yang dikutip oleh Sri Winarsi, menyatakan bahwa di dalam membicarakan hak ulayat tidak terlepas dalam membicarakan tanah kas desa atau tanah bondo desa. Teer Haar Bzn lebih lanjut menyatakan bahwa tanah bondo desa atau tanah kas desa adalah sebagian dari tanah masyarakat yang diperuntukkan bagi warga masyarakat di desa tersebut untuk dikelola bersama-sama dan untuk kesejahteraan seluruh warga. Pemanfaatan tanah kas desa di bawah koordinasi atau pengawasan kepala persekutuan. ${ }^{24}$

Lebih lanjut berkenaan dengan pembinaan dan pengembangan lembaga adat dalam Instruksi Mendagri kepada Gubernur dan Bupati/Walikota No. 17 Tahun 1985 tentang Pembinaan dan Pengembangan Lembaga Adat di wilayah Desa/Kelurahan pada huruf C dinyatakan, bahwa "mengatur ketentuan penginventarisasian sumber-sumber keuangan dan harta kekayaan lembaga adat yang dipergunakan untuk kegiatan pembangunan dan pembinaan kemasyarakatan". Membahas lembaga adat tidak terlepas dengan persoalan tanah adat yang disebut dengan Hak Ulayat. Lembaga-lembaga hukum adat yang dimaksudkan yaitu lembaga hukum adat yang diambil sebagai dasar utama pembentukan Hukum Agraria Nasional adalah susunan macammacam hak atas tanah. Macam-macam hak atas tanah dalam hukum adat seperti hak milik/hak yasan, hak pakai, hak sewa, hak membuka tanah, hak menikmati hasil hutan. Susunan macam-macam hak atas tanah yang demikian ini kemudian diangkat dan dijadikan dasar dalam penyusunan hak-hak atas tanah dalam Hukum Agraria Nasional sebagaimana yang diatur dalam pasal 16 UUPA. ${ }^{25}$

\footnotetext{
${ }^{23}$ Sri Hajati, "Penyederhanaan Macam Hak Atas Tanah Dalam Rangka Pembaharuan Hukum Agraria Nasional”, Yuridika, Vol. 21 No. 3, (Mei 2006), hlm. 240

24 Winarsi, Pengelolaan Tanah Kas, hlm. 412

${ }^{25}$ H. Muchsin, dkk, Hukum Agraria Indonesia - Dalam Perspektif Sejarah, (Bandung : PT. Refika Aditama, 2007), hal 69.
} 
Perkembangan selanjutnya sebagaimana yang tercantum dalam ketentuan pasal 3 UUPA yang menyatakan bahwa hak ulayat yang dimiliki oleh persekutuan diakui namun pelaksanaannya dilakukan dengan syarat: (1) Sepanjang kenyataan masih hidup; (2) sesuai dengan kepentingan nasional dan negara; (3) berdasarkan atas persatuan bangsa; (4) tidak boleh bertentangan dengan UndangUndang dan peraturan-peraturan yang lebih tinggi.

Berangkat dari ketentuan pasal 3 UUPA di atas, dalam konsep hukum responsif, bahwa hukum tanah nasional yang terdapat dalam UUPA termaksud telah mendapat respon dari hukum adat yang berasal dari masyarakat hukum adat yang secara turun temurun telah dipertahankan. Menurut pendapat Philippe Nonet dan Philip Selznick yang menyatakan, bahwa suatu institusi yang responsif mempertahankan secara kuat hal-hal yang esensial bagi integritasnya sembari tetap memperhatikan keberadaan kekuatan-kekuatan baru di dalam lingkungannya. Untuk melakukan hal ini, hukum responsif memperkuat cara-cara bagaimana keterbukaan dan integritas dapat saling menopang walaupun terdapat pertentangan diantara keduanya. ${ }^{26}$

Pelaksanaan hak ulayat yang dilakukan oleh Negara melalui berbagai peraturan memang mulai ada pembatasan-pembatasan. Lebih-lebih dengan dikeluarkannya Peraturan Menteri Dalam Negeri No. 28 Tahun 2006 tentang Pembentukan, Penghapusan, Penggabungan Desa dan Perubahan Status Desa Menjadi Kelurahan yang dalam pasal 12 ayat (1) menyatakan bahwa "Berubahnya status Desa menjadi Kelurahan, seluruh kekayaan dan sumber-sumber pendapatan Desa menjadi kekayaan Daerah Kabupaten/Kota". Lagilagi hal ini kembali pada masyarakat kita dalam merespon hadirnya berbagai peraturan.

Menurut pendapat Maria S.W. Sumardjono, bahwa berhadapan dengan lembaga hak atas tanah yang dikenal dengan sebutan hak ulayat ini bagi banyak pihak bagaikan buah simalakama. Jika cepat-cepat disimpulkan, hak ulayat yang dihadapi itu dianggap sudah tidak ada lagi, apalagi dengan dalih terselubung adanya kepentingan lain yang lebih besar dan mendesak, maka tindakan itu

26 Philippe Nonet dan Philip Selznick, Hukum Responsif, terj. Raisul Muttaqien, (Bandung: Nusamedia, 2007), hlm. 87. 
jelas bertentangan dengan prinsip pengakuan terhadap hak ulayat oleh UUPA yang dijabarkan dalam pasal 3.27

Pada kenyataannya bahwa UUPA dan hukum tanah nasional kita tidak menghapus hak ulayat, tetapi juga tidak akan mengaturnya. Mengatur hak ulayat dapat berkibat melanggengkan atau melestarikan eksistensinya. Padahal perkembangan masyarakat menunjukkan kecenderungan akan hapusnya hak ulayat tersebut melalui proses alamiah. Yaitu dengan menjadi kuatnya hak-hak perorangan dalam masyarakat hukum adat yang bersangkutan. ${ }^{28}$

\section{Tanah Kas Desa}

Ada beberapa bentuk atau status penguasaan tanah tradisional, yaitu: Pertama, tanah yasan, yasa atau yoso, yaitu tanah di mana hak seseorang atas tanah itu berasal dari kenyataan bahwa dia atau leluhurnyalah yang pertama-tama membuka atau mengerjakan tanah tersebut. Hak atas tanah ini memperoleh status legal dalam UUPA-1960 sebagai tanah milik. Kedua, tanah norowito, gogolan, pekulen, playangan, kesikepan, dan sejenisnya adalah tanah pertanian milik bersama, yang daripadanya para warga desa dapat memperoleh bagian untuk digarap, baik secara bergilir maupun secara tetap, dengan syarat-syarat tertentu. Untuk memperoleh hak garap itu, umumnya diperlukan syarat bahwa si calon itu harus suda kawin, mempunyai rumah dan pekarangan, serta bersedia melakukan kerja wajib bagi desa. Dalam konsep Barat, tanah ini dapat dikategorikan sebagai tanah milik komunal. Dalam UUPA-1960, hak atas tanah ini diubah statusnya menjadi tanah milik bagi penggarapnya yang terakhir. Ketiga, tanah titisara, bondo deso, kas desa adalah tanah milik desa yang biasanya disewakan, disakapkan, dengan cara dilelang kepada siapa yang mau menggarapnya. Hasilnya dipergunakan sebagai anggaran rutin ataupun pemeliharaan desa seperti memperbaiki jembatan, jalan, mesjid dan sebagainya. Keempat, tanah bengkok, yaitu tanah milik desa yang diperuntukkan bagi pejabat desa terutama lurah, yang hasilnya dianggap sebagai "gaji" selama mereka menduduki jabatan itu. Tanah bengkok dan tanah titisara ini

27 Maria S.W. Sumardjono, Kebijakan Pertanahan; antara Regulsi dan Implementasi, (Jakarta: PT. Kompas Media Nusantara, 2008), hlm. 64.

28 Boedi Harsono, Hukum Agraria Indonesia; Sejarah Pembentukan Undang-Undang Pokok Agraria, Isi dan Pelaksanaannya, (Jakarta: Djambatan, 1999), hlm. 189. 
dalam konsep Barat dapat digolongkan dalam kategori "tanah yang tunduk kepada pengawasan komunal". Dalam UUPA-1960 keduaduanya tetap diakui adanya. ${ }^{29}$

Dari berbagai bentuk atau status penguasaan tanah tradisional di atas, antara lain tanah kas desa, ada beberapa daerah yang menyebutnya dengan nama tanah titisara atau bondo deso. Hal itu tidak menjadi persoalan akan tetapi memiliki makna yang sama yaitu tanah milik desa, yang bagaimana pun cara pengelolaannya asalkan hasilnya dipergunakan untuk keperluan desa serta tidak boleh dipakai sebagai jaminan hutang maupun tidak boleh dialihkan kepada siapa pun dan dengan cara apapun kecuali untuk kepentingan umum ${ }^{30}$.

Dilihat secara historis dan yuridis asal usul tanah kas desa berbeda-beda. Menurut Wiradiputra, berdasarkan asal usulnya tanah kas desa itu dapat dibedakan menjadi dua, yaitu: (1) Tanah kas desa yang oleh desa dibeli dengan uang kas desa yang kemudian tanah tersebut sebagian diperuntukkan kesejahteraan masyarakat desa; (2) tanah kas desa yang bukan dari pembelian, tetapi dari tanah ulayat (tanah negara yang dihinggapi hak-hak Indonesia), yang diberikan khusus untuk itu oleh pemerintah. Pejabat yang dikuasakan adalah Residen (Bijblad-6535, Stb. 1925 No 434 Jo. Stb. 1931 No. 573 huruf C No. 6). ${ }^{31}$

Peruntukan tanah kas desa selain dipergunakan untuk mencukupi kebutuhan desa juga dipergunakan untuk kesejahteraan kepala desa beserta perangkatnya yang juga disebut dengan tanah bengkok, karena mereka tidak mendapatkan gaji. Berkenaan dengan tanah bengkok, menurut Eman Ramelan yang dikutip oleh Sri Winarsi, bahwa elemen-elemen tanah bengkok adalah: (1) Tanah bengkok merupakan bagian dari tanah hak ulayat; (2) tanah bengkok diberikan kepada warga desa yang sedang menjabat sebagai kepala desa atau pamong desa; (3) pemberian tanah tersebut hanya

\footnotetext{
29 Sediono M.P. Tjondronegoro dan Gunawan Wiradi (eds.), Dua Abad Penguasaan Tanah; Pola Penguasaan Tanah Pertanian di Jawa dari Masa ke Masa, (Jakarta: PT. Gramedia, 1984), hal 293 - 295

30 Kepentingan umum diartikan sebagai kepentingan bagi seluruh rakyat pada umumnya termasuk kepentingan bangsa dan negara yang tujuannya adalah untuk kesejahteraan, hal ini didasari dari ketentuan pasal 18 UUPA.

31 Winarsi, Pengelolaan Tanah, hlm. 414
} 
sementara waktu yaitu selama yang bersangkutan menjabat sebagai kepala desa atau pamong desa; (4) maksud pemberian tanah tersebut sebagai upah atau ganjaran untuk menghidupi diri dan keluarga kepala desa atau pamong desa. 32

Tanah bengkok yang dimaksud di atas dalam Hukum Adat juga dikenal dengan istilah tanah jabatan, yaitu untuk menjamin penghasilan para pejabat desa, setiap pejabat desa memiliki hak atas tanah jabatan. Hak tersebut adalah mengerjakan dan menyewakan. Jadi kalau mereka diberhentikan dari jabatannya, tanah jabatan tersebut harus dikembalikan kepada hak purba desa. Hak Purba adalah hak pertuanan dan juga disebut dengan hak ulayat. ${ }^{33}$ Menyinggung hak pertuanan, Van Vollenhoven berpendapat bahwa bechikkingsrecht atau hak pertuanan tidak boleh dipindah tangankan. ${ }^{34}$ Tanah bengkok dalam suatu desa tidak terlepas dengan tanah kas desa atau tanah bondo desa, yang juga merupakan bagian dari tanah hak ulayat.

Menurut PP No. 72 tahun 2005 tentang Desa, dalam pasal 68 ayat (1) huruf a disebutkan bahwa "pendapatan asli desa, terdiri dari usaha desa, hasil kekayaan desa, hasil swadaya dan partisipasi, hasil gotong royong, dan lain-lain pendapatan asli desa yang sah." Kekayaan desa yang dimaksudkan di atas, terdiri atas: (1) Tanah kas Desa; (2) pasar desa; (3) pasar hewan; (4) tambatan perahu; (5) bangunan desa; (6) pelelangan ikan yang dikelola oleh desa; dan (7) lain-lain kekayaan milik desa. ${ }^{35}$

Ketentuan lebih lanjut mengenai sumber pendapatan desa sebagaimana dimaksud dalam Pasal 68 ayat (1) diatur dengan Peraturan Daerah Kabupaten/Kota. ${ }^{36}$ Pasal 15 Permendagri No. 4 Tahun 2007 yang mengatur tentang Pedoman Pengelolaan Kekayaan Desa menyebutkan bahwa: (1) Kekayaan desa yang berupa tanah Desa tidak diperbolehkan dilakukan pelepasan hak kepemilikan kepada pihak lain, kecuali diperlukan untuk kepentingan umum; (2)

\footnotetext{
32 Ibid, hlm. 416

33 Iman Soediyat, Asas-asas Hukum Adat, Bahan Kuliah tahun 1968 - 1969; (Yogyakarta: Fakultas Hukum Universitas Gajah Mada, t.th.)

34 Ter Haar Bzn, Asas-asas dan Susunan Hukum Adat, terj. Soebakti Poesponoto, (Jakarta: Pradnya Paramita, 1983), hlm. 72.

35 Pasal 69 PP No. 72 Tahun 2005

36 Pasal 72 ayat (1) PP No. 72 Tahun 2005
} 
Pelepasan hak kepemilikan tanah desa sebagaimana dimaksud pada ayat (1) dilakukan setelah mendapat ganti rugi sesuai dengan harga yang menguntungkan desa dengan memperhatikan harga pasar dan Nilai Jual Objek Pajak (NJOP); (3) penggantian ganti rugi berupa uang harus digunakan untuk membeli tanah lain yang lebih baik dan berlokasi di desa setempat; (4) pelepasan hak kepemilikan tanah desa sebagaimana dimaksud pada ayat (1) ditetapkan dengan keputusan kepala desa; (5) keputusan kepala desa sebagaimana dimaksud pada ayat (3) diterbitkan setelah mendapat ijin tertulis dari bupati/walikota dan gubernur. Pengaturan tentang Tanah Kas Desa selanjutnya diatur dalam Perda kabupaten/kota yang menjadi wilayah kewenangannya.

\section{Catur Tertib Pertanahan}

Sesuai dengan situasi dan kondisi keagrarian di Indonesia dan tujuan akan mewujudkan masyarakat adil dan makmur berdasarkan Pancasila (pada waktu itu sosialisme Indonesia), agrarian reform Indonesia yang meliputi 5 program (panca program), yaitu: (1) Pembaruan hukum agraria, melalui unifikasi hukum yang berkonsepsi nasional dan pemberian jaminan kepastian hukum; (2) penghapusan hak-hak asing dan konsesi-konsesi kolonial atas tanah; (3) mengakhiri penghisapan feodal secara berangsur-angsur; (4) perombakan pemilikan dan penguasaan tanah serta hubunganhubungan hukum yang bersangkutan dengan pengusahaan tanah dalam mewujudkan pemerataan kemakmuran dan keadilan; (5) perencanaan persediaan dan peruntukan bumi, air dan kekayaan alam yang terkandung di dalamnya serta penggunaannya secara terencana, sesuai dengan daya dukung dan kemampuannya. ${ }^{37}$

Perjalanan waktu dalam melakukan reformasi di bidang pertanahan diharapkan dapat lebih berpihak pada rakyat utamanya rakyat kecil atau petani-petani tanpa lahan atau buruh tani yang telah menjadi amanat dalam reformasi pertanahan (land reform) yang mempunyai tujuan untuk mengatasi ketimpangan dalam penguasaan dan pemilikan tanah pertanian yang terjadi pada masa sebelumnya, dengan melakukan perombakan terhadap stuktur penguasaan dan pemilikannya. Prinsip yang terkadung dalam Land Reform adalah

\footnotetext{
37 Harson, Hukum Agraria Indonesia, hlm. 3-4.
} 
tanah-tanah pertanian yang dimiliki oleh mereka yang bukan petani atau mereka yang tidak dapat mengerjakan sendiri secara aktif tanah pertaniannya. Misalnya, pada tanah absentee (yaitu tanah-tanah yang letaknya di kecamatan berbeda dengan pemiliknya), atau pada mereka yang pemilikan tanahnya melampaui batas yang ditentukan atau pemetakan tanah-tanah pertanian menjadi bagian-bagian kecil kurang dari 2 Ha. Tanah-tanah tersebutlah yang menjadi obyek Land Reform yang selanjutnya akan dikuasai oleh negara dan kepada pemiliknya diberikan ganti rugi. Serta untuk selanjutnya tanah bekas Land Reform tersebut didistribusikan kepada para petani dengan pemberian hak milik.

Ketentuan land reform ini selaras dengan apa yang telah menjadi amanat dari pasal 6 UUPA, yang menyatakan bahwa, "Semua hak atas tanah mempunyai fungsi sosial". Ini berarti bahwa hak atas tanah apapun yang ada pada seseorang, tidaklah dapat dibenarkan, bahwa tanahnya itu akan dipergunakan (atau tidak dipergunakan) semata-mata untuk kepentingan pribadinya, apalagi kalau hal itu menimbulkan kerugian bagi masyarakat. Penggunaan tanah harus disesuaikan dengan keadaannnya dan sifat daripada haknya, hingga bermanfaat baik bagi kesejahteraan dan kebahagiaan yang mempunyainya maupun bermanfaat pula bagi masyarakat dan Negara. ${ }^{38}$ Dengan demikian, tanah harus dipergunakan sesuai dengan fungsi dan peruntukannya sehingga bermanfaat baik bagi kesejahteraan dan kebahagiaan yang memilikinya maupun bagi masyarakat dan negara. ${ }^{39}$

Petani yang diberikan tanah tersebut adalah petani yang diutamakan mereka yang sebelumnya tidak memiliki tanah pertanian (sawah). Mereka adalah: (1) Para penyewa yang menggarap tanah; (2) para buruh tani yang menggarap sawah; (3) pekerja tetap atas tanah; (5) penyewa-penyewa yang menggarap tanah dalam jangka waktu kurang dari 3 (tiga) tahun. ${ }^{40}$

Menurut pendapat South Cetre, yang dikutip Bonnie Setiawan, menyatakan bahwa selain land reform juga ada bentuk-

\footnotetext{
${ }^{38}$ Lihat penjelasan umum II angka 4 UUPA

${ }^{39}$ Muchsin, Menggagas Pelaksanaan Tata Guna Tanah; Kajian Yuridis, Filosofis, Normatif, dan Sosiologis, (Surabaya: Dunia Ilmu, 1998), hlm. 1.

40 Eman Ramelan, "Hukum Agraria dan Reforma Pertanahan di Indonesia", Yuridika, Vol. 18 No. 4, (Juli 2003), hlm. 300.
} 
bentuk upaya pembaruan lain yang juga berkaitan, yaitu: (1) pembaruan penyakapan (tenancy reform); (2) pemindahan dan pembukaan tanah baru (settlement schemes); (3) bantuan khusus bagi petani kecil; dan (4) pajak tanah progrsif. ${ }^{41}$

Dengan dikeluarkannya Ketetapan MPR No. IX/MPR/2001 tentang Pembaruan Agraria dan Pengelolaan Sumberdaya Alam, khusunya pada pasal 2 menyebutkan bahwa, "pembaruan agraria mencakup suatu proses yang berkesinambungan berkenaan dengan penataan kembali penguasaan, pemilikan, penggunaan dan pemanfaatan sumberdaya agraria dilaksanakan dalam rangka tercapainya kepastian dan perlindungan hukum serta keadilan dan kemakmuran bagi seluruh rakyat Indonesia."

Begitu pula dalam Undang-undang No. 17 Tahun 2007 tentang Rencana Program Pembangunan Jangka Panjang Nasional tahun 2005 - 2025 pada Bab IV.1.5 Mewujudkan Pembangunan yang Lebih Merata dan Berkeadilan angka 11, yang menyebutkan, menerapkan sistem pengelolaan pertanahan yang efisien, efektif serta melaksanakan penegakan hukum terhadap hak atas tanah dengan menerapkan prinsip-prinsip keadilan, transparansi dan demokrasi. Selain itu perlu dilakukan penyempurnaan penguasaan, pemilikan, penggunaan dan pemanfaatan tanah melalui perumusan berbagai aturan pelaksanaan land reform serta penciptaan insentif/disinsentif perpajakan yang sesuai dengan luas, lokasi dan penggunaan tanah agar masyarakat golongan ekonomi lemah dapat lebih mudah mendapatkan hak atas tanah. Selain itu menyempurnakan sistem hukum dan produk hukum pertanahan melalui inventarisasi dan penyempurnaan peraturan perundang-undangan pertanahan dengan mempertimbangkan aturan masyarakat adat, serta peningkatan upaya penyelesaian baik melalui kewenangan administrasi, peradilan maupun alternative dispute resolution. Selain itu akan dilakukan penyempurnaan kelembagaan pertanahan sesuai dengan semangat otonomi daerah dan dalam kerangka Negara Kesatuan Republik Indonesia, terutama yang berkaitan dengan peningkatan kapasitas sumber daya manusia bidang pertanahan di daerah.

\footnotetext{
41 Bonnie Setiawan, “Konsep Pembaruan Agraria : Sebuah Tinjauan Umum”, dalam Prinsip-Prinsip Reforma Agraria; Jalan Penghidupan dan Kemakmuran Rakyat, (Yogyakarta: Lapera Pustaka Utama, 2001), hlm. 30
} 
Dari ketetapan MPR dan UU No. 17 Tahun 2007 tersebut, diharapkan untuk menjamin adanya kepastian hukum atas bidang tanah dilakukan berbagai upaya hukum untuk melindunginya, maka harus dilakukan pendaftaran hak atas tanahnya sehingga tercapai kepastian dan perlindungan hukum. Kebijakan pertanahan diwujudkan dalam kerangka tertib pertanahan yang disebut dengan catur tertib pertanahan, yaitu tertib hukum pertanahan, tertib administrasi pertanahan, tertib penggunaan tanah dan tertip pemeliharaan tanah dan lingkungan hidup. Kebijakan pertanahan ini sejalan dengan amanat dari Pelita III sebagai pelaksana dari Tap MPR No. IV/MPR/1979.

\section{Pendaftaran Tanah kan Konversi}

Dilakukannya pendaftaran tanah dengan tujuan terwujudnya kepastian hak atas tanah. Dengan kepastian hak setidak-tidaknya akan dapat dicegah sengketa tanah. Dalam proses pendaftaran tanah akan diterbitkan Sertipikat tanah, yang terdiri dari buku tanah dan surat ukur sehingga keberadaan tanah tersebut ada suatu kepastian baik berkenaan dengan pemegang hak atau subyek hak, hak atas tanahnya atau obyekny a hak serta yang utama pula tanah tersebut sudah terdaftar di kantor pendaftaran tanah atau Badan Pertanahan Nasional sehingga setiap orang dapat mengetahui bahwa tanah tersebut telah ada pemiliknya.

Kenyataannya di lapangan pendaftaran tanah yang menjadi amanat Pasal 19 ayat (1) UUPA Jo. PP No. 24 Tahun 1997 tentang Pendaftaran Tanah tidak membuahkan hasil yang menggembirakan. Pendaftaram tanah diselenggarakan dalam rangka menjamin kepastian hukum di bidang pertanahan (rechtskadarter atau legal cadastre). ${ }^{42}$

Pendaftaran tanah merupakan kewajiban bagi pemerintah yang harus dilaksanakan secara terus menerus dan juga kewajiban bagi setiap pemegang hak atas tanah, baik pendaftaran yang dilaksanakan untuk pertama kalinya maupun pendaftaran hak setiap terjadinya peralihan dan pembebanan hak. Salah satu faktor penyebabnya adalah tingkat kesulitan yang dialami oleh masyarakat. Prosesnya lama dan biayanya mahal. Pelayanan kantor pertanahan

42 Soerodjo, Kepastian Hukum, hlm. 106. 
dilihat dari aspek administrasi juga belum mampu memberikan kinerja yang diharapkan yaitu pelayanan yang sederhana, aman, terjangkau dan transparan. Kenyataan yang terjadi adalah pelayanan yang masih lambat, sulit, mahal dan berbelit-belit serta memungkinkan terjadinya malpraktik.43 Keengganan masyarakat untuk melakukan pendaftaran tanahnya karena selalu ada faktor X yang menghantui mereka. Sungguhpun pada beberapa kantor Pertanahan telah dicantumkan biaya pendaftaran tanah, demikian pula biaya-biaya lainnya apalagi dengan adanya biaya pajak yang diperhitungkan dengan NJOP untuk setiap mutasi. ${ }^{44}$

Masih menurut pendapat Andrian Sutedi, bahwa pada dasarnya tujuan pendaftaran tanah adalah untuk meningkatkan kesejahteraan rakyat. Dalam mencapai tujuan tersebut sasaran pemerintahan dalam mengelola pertanahan adalah catur tertib pertanahan yaitu tertib hukum pertanahan, tertib administrasi pertanahan, tertib penggunaan tanah dan tertib pemeliharaan tanah dan lingkungan hidup..$^{45}$

Menurut pendapat Sir Charles Fortescue-Brickdate. ada 6 hal yang harus digabungkan dalam pendaftaran tanah, yaitu: (1) Security, bertolak dari kemantapan sistem sehingga seseorang akan merasa aman atas hak tersebut baik karena membeli tanah tersebut ataupun mengikatkan tanah tersebut untuk suatu jaminan atas utang (utang); (2) simplicity, sederhana sehingga setiap orang dapat mengerti; (3) accuracy, bahwa terdapat ketelian dari sistem pendaftaran tersebut secara lebih efektif; (3) expedition, artinya dapat lancar dan segera sehingga menghindari tidak jelas yang bisa berakibat berlarut-larut dalam pendaftaran tanah tersebut; (4) cheapness, yaitu agar biaya tersebut dapat semurah mungkin; (5) suitability to circumstances, yaitu akan tetap berharga baik sekarang maupun kelak di kemudian hari pendaftaran tersebut; (6) completeness of the record, terdiri atas: (a) perekan tersebut harus lengkap lebih-lebih lagi masih ada tanahtanah yang belum terdaftar; dan (b) demikian pula pendaftaran dari

43 Sutedi, Implementasi Prinsip, hlm. 1.

44 AP. Parlindungan, Komentar atas Undang-Undang Perumahan dan Permukiman $\mathcal{E}$ Undang-Undang Rumah Susun, (Bandung: Mandar Maju, 2001), hlm. 180.

45 Ibid, hlm. 2 
setiap tanah tertentu dengan berdasarkan keadaan pada waktu didaftarkan. 46

Desa juga harus diberikan kewenangan untuk menentukan dan mengelola sendiri aset atau kekayaan desa walaupun pemerintah daerah hadir didalamnya tetapi bertindak sebagai kontrol. Hal ini sejalan dengan ketentuan pasal 5 huruf 1 Ketetapan MPR No. IX/MPR/2001, yang menyatakan bahwa "Pembaruan agraria dan pengelolaan sumberdaya alam harus dilaksanakan sesuai dengan prinsip-prinsip melaksanakan desentralisasi berupa pembagian kewenangan di tingkat nasional, daerah provinsi, kabupaten/kota, dan desa atau yang setingkat, berkaitan dengan alokasi dan manajemen sumberdaya agraria dan sumberdaya alam".

\section{Pendaftaran Tanah Berdasarkan Ketentuan PP No. 24 Tahun 1997}

Berdasarkan ketentuan pasal 3 PP No. 24 Tahun 1997, tujuan diadakannya pendaftaran tanah adalah: (1) Untuk memberikan kepastian hukum dan perlindungan hukum kepada pemegang hak atas suatu bidang tanah, satuan rumah susun dan hak-hak lain yang terdaftar agar dengan mudah dapat membuktikan dirinya sebagai pemegang hak yang bersangkutan; (2) untuk menyediakan informasi kepada pihak-pihak yang berkepentingan termasuk pemerintah agar dengan mudah dapat memperoleh data yang diperlukan dalam mengadakan perbuatan hukum mengenai bidang-bidang tanah dan satuan-satuan rumah susun yang sudah terdaftar; dan (3) untuk terselenggaranya tertib administrasi pertanahan.

Dalam rangka memberikan kepastian dan perlindungan hukum kepada pemegang hak atas tanah akan diterbitkan Sertipikat Hak Atas Tanah, yang merupakan kumpulan dari salinan buku tanah dan surat ukur. Buku Tanah memuat nama dari pemegang hak atas tanah dan status kepemilikannya. Sedangkan Surat Ukur memuat tentang letak tanah, luas tanah dan batas-batas dari tanah yang bersangkutan. Adanya kepastian tentang subyek hukum dan obyek hak.

Asas yang dianut dalam PP No. 24 Tahun 1997, sebagaimana diatur dalam pasal 2, yaitu:

46 Supriadi, Hukum Agraria, (Jakarta: Sinar Grafika, 2007), hlm. 166. 
1. Asas sederhana, maksudnya dalam pendaftaran tanah dimaksud agar ketentuan-ketentuan pokoknya maupun prosedurnya dengan mudah dapat dipahami oleh pihak-pihak yang berkepentingan terutama para pemegang hak atas tanah. Sedangkan Asas Aman, yaitu dalam pendaftaran tanah perlu diselenggarakan secara teliti dan cermat sehingga hasilnya dapat memberikan jaminan kepastian hukum sesuai tujuan pendaftaran tanah itu sendiri.

2. Asas terjangkau, dimaksudkan keterjangkauan bagi pihak-pihak yang memerlukan, khususnya dengan memperhatikan kebutuhan dan kemampuan golongan ekonomi lemah. Pelayanan yang diberikan dalam rangka penyelenggaraan pendaftaran tanah harus bisa terjangkau oleh para pihak yang memerlukan.

3. Asas mutakhir, dimaksudkan kelengkapan yang memadai dalam pelaksanaannya dan keseimbangan dalam pemeliharaan datanya. Dua yang tersedia harus menunjukkan keadaan yang mutakhir. Untuk itu perlu diikuti kewajiban mendaftar dan pencatatan perubahan-perubahan yang terjadi di kemudian hari. Asas mutakhir menuntut dipeliharanya data pendaftaran tanah secara terus menerus dan berkesinambungan, sehingga data yang tersimpan di kantor pertanahan selalu sesuai dengan keadaan nyata di lapangan, dan masyarakat dapat memperoleh keterangan mengenai data yang benar setiap saat. Untuk itulah diberlakukan pada asas terbuka (publisitas).

Pendaftaran tanah dapat dilakukan, pendaftaran tanah untuk pertama kalinya yaitu pendaftaran hak yang sebelumnya belum pernah dilakukan pembukuan atau pendataan di Kantor Pertanahan dan pendaftaran hak karena terjadinya peralihan kepemilikan atau terjadinya pembebanan hak (agunan hutang). Penyelenggaraan pendaftaran tanah pada saat ini melalui 2 (dua) pendekatan: Pertama, melalui pendekatan sistematik. Kedua, melalui pendekatan sporadik. Sebagian besar penyelenggaraan pendaftaran tanah sekarang ini melalui sporadik yang berdasarkan permohonan masyarakat, hal ini disebabkan kemampuan pemerintah untuk menyelenggarakan pendekatan sistematik terbatas. ${ }^{47}$

47 Sutedi, Implementasi Prnsip Kepentingan, hlm. 5 
Pendaftaran tanah secara sistematik adalah kegiatan pendaftaran tanah untuk pertama kali yang dilakukan secara serentak yang meliputi semua obyek pendftaran tanah yang belum didaftar. Sedangkan pendaftaran tanah secara sporadik adalah kegiatan pendaftaran tanah untuk pertama kali mengenai satu atau beberapa obyek pendaftaran tanah dalam wilayah atau bagian wilayah suatu desa/kelurahan secara individual atau masal.48 Obyek pendaftaran tanah yang diatur dalam pasal 9 PP No. 24 Tahun 1997, meliputi: (1) Bidang-bidang tanah yang dipunyai dengan hak milik, hak guna usaha, hak guna bangunan dan hak pakai; (2) tanah hak pengelolaan; (3) tanah wakaf; (4) hak milik atas satuan rumah susun; (5) hak tanggungan; dan (6) tanah Negara.

Ketentuan pasal 9 di atas, tidak menyebutkan Tanah Kas Desa sebagai obyek pendaftaran karena memang istilah Tanah Kas Desa dalam ketentuan pasal 16 ayat (1) tidak dimasukkan karena dengan berlakunya UUPA, Tanah Kas Desa harus dilakukan konversi atau disesuaikan dengan hak-hak atas tanah yang terdapat dalam ketentuan pasal 16 ayat (1) UUPA. Konversi dari Tanah Kas Desa menjadi Hak Pakai dengan jangka waktu yang tidak terbatas, dengan ketentuan tanah tersebut masih dipergunakan sesuai dengan peruntukannya. Hak Pakai inilah yang kemudian dalam ketentuan pasal 9 PP No. 24 Tahun 1997 termasuk dalam obyek pendaftaran hak atas tanah.

Namun demikian, parlu diingat bahwa Tanah Kas Desa yang dikonversi menjadi Hak Pakai adalah Hak Pakai publikrechtelijk, artinya hanya ada right to use karena hak tersebut tidak boleh dialihkan dan tidak dapat dipakai sebagai jaminan hutang dengan dibebani hak tanggungan, kecuali untuk kepentingan umum. PP No. 24 Tahun 1997 menganut sistem publikasi negatif menuju ke sistem publikasi positif dalam jangka waktu lima tahun, ${ }^{49}$ maksudnya bilamana atas suatu bidang tanah tersebut telah diterbitkan sertipikat dengan iktikat baik, maka setelah lewat lima tahun sejak penerbitan sertipikat tersebut tidak boleh diajukan gugatan. Gugatan boleh diaukan dalam tenggang waktu lima tahun.

\footnotetext{
48 Pasal 1 angka 11 dan 12 PP No. 24 Tahun 1997

49 Pasal 32 ayat (2) PP No. 24 Tahun 1997
} 
Umi Supraptiningsih

\section{Ketentuan Konversi}

Hak atas tanah yang disebutkan dalam ketentuan pasal 16 ayat (1) dan pasal 53 UUPA merupakan hak atas tanah yang telah dikonversi atau disesuaikan dengan hak atas tanah yang telah diatur dalam UUPA. Baik hak atas tanah yang berasal dari hukum Barat maupun hak atas tanah yang berasal dari hukum adat.

Berkaitan dengan tanah kas desa yang semula berasal dari tanah adat, hal ini diatur dalam Pasal IV Ketentuan Konversi, yaitu hak-hak atas tanah yang memberi wewenang sebagaimana atau mirip dengan hak yang dimaksud dalam pasal 41 ayat (1) seperti yang disebut dengan nama sebagi dibawah yang ada pada mulai berlakunya undang-undang ini yaitu: Hak Vruchgebruik, gebruik, grant controleur, bruikleen, ganggam bauntuik, anggaduh, bengkok, lungguh, pituas dan hak-hak lain dengan nama apa pun juga, yang akan ditegaskan lebih lanjut oleh Menteri Agraria, sejak mulai berlakunya undang-undang ini menjadi hak pakai tersebut dalam pasal 41 ayat (1) yang memberi wewenang dan kewajiban sebagaimana yang dipunyai oleh pemegang haknya pada mulai berlakunya undangundang ini, sepanjang tidak bertentangan dengan jiwa dan ketentuan undang-undang ini.

Menurut komentar AP. Parlindungan, bahwa hak-hak tanah ex Barat akan menjadi Hak Pakai atas Tanah Milik, sedangkan hakhak lain menurut Hukum Adat akan menjadi Hak Pakai. Khusus mengenai tanah-tanah jabatan seperti tanah bengkok, kalaupun dikonversi menjadi Hak Pakai tentunya harus Hak Pakai publikrechtelijk, artinya hanya ada right to use, tetapi tidak ada right of disposal untuk menghindari dialihkannya/dijadikan obyek tanggungan oleh orang yang tidak bertanggung jawab, oleh karena tanah itu adalah tanah jabatan kepala desanya. Termasuk kategori ini, tanah kas desa dan tanah-tanah sejenis yang merupakan tanah bengkok dan tanah kas desa diberikan Hak Pakai Publikrechtelijk, yaitu hanya ada right to use tetapi tidak ada right to disposal (tidak boleh dijual atau dijadikan agunan hutang). ${ }^{50}$

Tanah Kas Desa dalam sistem hukum tanah nasional telah dikonversi menjadi Hak Pakai Publikrechtelijk bukan Hak Pakai

\footnotetext{
50 AP. Parlindungan, Komentar atas Undang-Undang Pokok Agraria, (Bandung: CV. Mandar Maju, 1998), hlm. 255
} 
Privaatrechtelijk. Lebih lanjut AP. Parlindungan memberikan beberapa uraian tentang Hak Pakai Publikrechtelijk, yaitu sebagai berikut:

1. Right to use-nya adalah untuk mempergunakan tanah untuk pelaksanaan tugasnya, dan pelaksanaan tugasnya itu tergantung dari tugas yang khusus seperti untuk universitas-universitas negeri sebagai "Pelaksanaan Pendidikan Tinggi".

2. Jangka waktu hak ini, tidak terbatas selama masih melaksanakan tugasnya tersebut, umpamanya tanah tersebut untuk kompleks militer, selama masih dipergunakan, selama itu hak pakai itu tetap ada, namun jika kompleks itu pindah dan tidak dipergunakan lagi, maka pada saat itu pula hak itu berakhir, dan kembali pada pemerintah.

3. Subyek dari hak ini adalah: (a) Publikrechtelijk adalah departemen/ditjen, lembaga pemerintah non departemen, pemerintah daerah dan lain-lain, lihat PMDN No. 6 Tahun 1972; (b) publikrechtelijk internasional, perwakilan-perwakilan negaranegara asing51; (c) publikrechtelijk agama/sosial, lembaga-lembaga keagamaan dan lembaga sosial, dan dapat kita lihat pada pasal 49 UUPA, yang menyebutkan bahwa untuk keperluan peribadatan dan keperluan suci lainnya sebagai dimaksud dalam pasal 124 dapat diberikan tanah yang dikuasaai langsung oleh Negara dengan Hak Pakai.

4. Right of disposal, yaitu: (a) Hak ini tidak dapat dialihkan kepada siapapun, karena memang tidak dimaksudkan berada dalam lalu lintas perdagangan; dan (b) tidak dapat dijadikan agunan pinjaman hutang/hak tanggungan.

5. Pendaftaran Hak, di mana hak ini harus didaftarkan di Kantor Pendaftaran Tanah.

6. Wewenang pemberian hak: ada pada Gubernur Kdh (sekarang Kepala Kanwil BPN) berdasarkan pasal 5 ayat b PMDN No. 6/1972.

7. Berakhirnya haknya dengan berakhirnya pula right or use-nya.

8. Peralihan hak : sebagaimana sudah diterangkan sebelumnya, maka hak ini tidak dapat dialihkan (melalui PPAT), namun juka tidak dipergunakan lagi, dapat saja dengan segala cara

\footnotetext{
51 lihat pasal 1 ayat 2 Ketentuan konversi, yang menyebutkan hak ini yang akan
} berlangsung selama tanahnya dipergunakan untuk keperluan tersebut 
Umi Supraptiningsih

melepaskan hak ini kembali kepada negara dan pihak yang memohon dapat meminta kepada BPN untuk memperoleh hak ini, namun terserah kepada pemberi hak untuk memperkenankan ataupun tidakmeluluskannya, karena BPN tidak ada keharusan untuk tunduk pada sesuatu "perjanjian" yang diperbuat.

9. Dasar hukum dari Hak Pakai Publikrechtelijk ini adalah pasal 49 UUPA, PMA No. 9/1965 dan PMDN No. 6 Tahun 1972 pasal 5 ayat $\mathrm{b}$ dan pasal I ayat $2 \mathrm{KK} .52$

\section{Penutup}

Dalam rangka memberikan perlindungan terhadap bidangbidang tanah serta tanah aset desa berupa tanah kas desa, maka diperlukanlah tindakan-tindakan penertiban. Sudah menjadi kewajiban dari kepala desa atau kepala kelurahan untuk menerapkan berbagai peraturan sebagai tindakan preventif dalam menjaga dan melindungi hak warganya serta tanah aset desa tersebut. Salah satunya yaitu dengan melakukan pendataan dan pencatatan secara tertib, bilamana terjadi perubahan (mutasi) atas bidang-bidang tanah yang berada di wilayahnya. Berkenaan dengan tanah kas desa, perlunya dilakukan pendaftaran tanah, sehingga ada kepastian hukum. Tidak dilakukan peralihan dan pembebanan hak atas tanah kas desa kecuali untuk kepentingan umum, begitu pula hasil pembayaran ganti ruginya harus dibelikan tanah kas desa yang kualitasnya sama atau lebih bagus.

\section{Daftar Pustaka}

Bakri, Muhammad. Hak Menguasai Tanah oleh Negara; Paradigma Baru untuk Reformasi Agraria. Jakarta: Citra Media, 2007

Bzn, Ter Haar. Asas-asas dan Susunan Hukum Adat, terj. Soebakti Poesponoto. Jakarta: Pradnya Paramita, 1983

Effendie, Bachtiar. Kumpulan Tulisan tentang Hukum Tanah. Bandung: Alumni, 1993

52 AP. Parlindungan, Hak Pengelolaan Menurut Sistem UUPA (Undang-Undang Pokok Agraria), Cet. II, (Bandung : CV. Mandar Maju, 1994), hlm. 92 - 94 
Hajati, Sri. "Penyederhanaan Macam Hak Atas Tanah Dalam Rangka Pembaharuan Hukum Agraria Nasional", Yuridika, Vol. 21 No. 3, (Mei 2006)

Harsono, Boedi Hukum Agraria Indonesia; Sejarah Pembentukan Undang-Undang Pokok Agraria, Isi dan Pelaksanaannya. Jakarta: Djambatan, 1999

Harsono, Boedi. Hukum Agraria Indonesia; Himpunan Peraturanperaturan Hukum Tanah. Jakarta: Djambatan, 2006

Hatta, Mohammad. Hukum Tanah Nasional dalam Perspektif Negara Kesatuan. Yogyakarta: Media Abadi, 2005

Junita, Fifi. "Hak Ulayat Hukum Adat Setelah Berlakunya UndangUndang No. 5 Tahun 1960 tentang Pokok-Pokok Ketentuan Agraria", Yuridika, Volume 16 No. 5, (September 2001)

Muchsin, dkk, Hukum Agraria Indonesia; dalam Perspektif Sejarah. Bandung : PT. Refika Aditama, 2007

Muchsin, Menggagas Pelaksanaan Tata Guna Tanah; Kajian Yuridis, Filosofis, Normatif, dan Sosiologis. Surabaya: Dunia Ilmu, 1998

Murad, Rusman. Penyelesaian Sengketa Hukum atas Tanah. Bandung: Alumni, 1991

Nonet, Philippe dan Selznick, Philip Hukum Responsif, terj. Raisul Muttaqien. Bandung: Nusamedia, 2007

Parlindungan, AP. Hak Pengelolaan Menurut Sistem UUPA (UndangUndang Pokok Agraria). Bandung : CV. Mandar Maju, 1994

Parlindungan, AP. Komentar atas Undang-Undang Perumahan dan Permukiman \& Undang-Undang Rumah Susun. Bandung: Mandar Maju, 2001

Parlindungan, AP. Komentar atas Undang-Undang Pokok Agraria. Bandung: CV. Mandar Maju, 1998

Ramelan, Eman. "Hukum Agraria dan Reforma Pertanahan di Indonesia", Yuridika, Vol. 18 No. 4, (Juli 2003) 
Umi Supraptiningsih

Ruchiyat, Edy. Politik Pertanahan Nasional sampai Orde Reformasi. Bandung: PT. Alumni, 2006

Setiawan, Bonnie. “Konsep Pembaruan Agraria : Sebuah Tinjauan Umum", dalam Prinsip-Prinsip Reforma Agraria; Jalan Penghidupan dan Kemakmuran Rakyat. Yogyakarta: Lapera Pustaka Utama, 2001

Sitorus, Oloan dan Nomadyawati, Hak atas Tanah dan Kondominium; Suatu Tinjauan Hukum. Jakarta: Dasamedia utama, 1994

Soediyat, Iman. Asas-asas Hukum Adat, Bahan Kuliah tahun 1968 - 1969. Yogyakarta: Fakultas Hukum Universitas Gajah Mada, t.th.

Soerodjo, Irawan. Kepastian Hukum Hak Atas tanah di Indonesia. Surabaya: Arkola, 2003

Soetomo, Politik dan Administrasi Agraria. Surabaya: Usaha Nasional, 1986

Sumardji, "Eksistensi, Pendaftaran, dan Pembebanan Hak Pengelolaan", Yuridika, Vol. 15 No. 1, (Januari 2000)

Sumardjono, Maria S.W. Kebijakan Pertanahan; antara Regulasi dan Implementasi. Jakarta: PT. Kompas Media Nusantara, 2008

Sumardjono, Maria S.W. Tanah dalam Perspektif Hak Ekonomi Sosial dan Budaya. Jakarta: Kompas, 2008

Supriadi, Hukum Agraria. Jakarta: Sinar Grafika, 2007

Sutedi, Andrian. Implementasi Prinsip Kepentingan Umum - dalam Pengadaan Tanah Untuk Pembangunan. Jakarta: Sinar Grafika, 2007

Tjondronegoro, Sediono M.P. dan Wiradi, Gunawan (eds.), Dua Abad Penguasaan Tanah; Pola Penguasaan Tanah Pertanian di Jawa dari Masa ke Masa. Jakarta: PT. Gramedia, 1984

Winarsi, Sri. "Pengelolaan Tanah Kas Desa di Era Otonomi Daerah", Yuridika, Vol. 29 No. 5, (September 2005) 